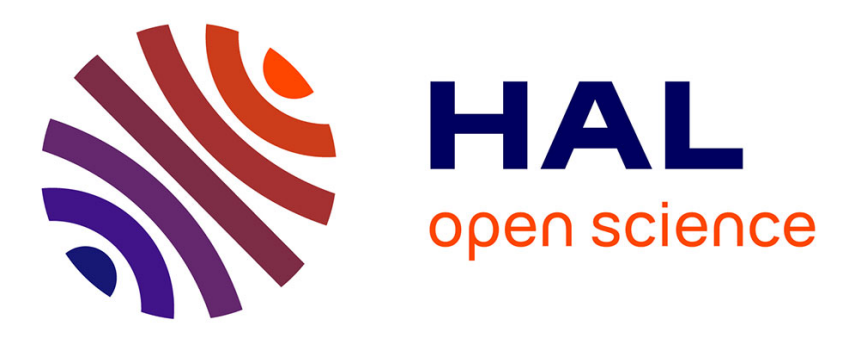

\title{
Dirhodium(II)-Mediated Alkene Epoxidation with Iodine(III) Oxidants
}

\author{
Ali Nasrallah, Gwendal Grelier, Maria Ivana Lapuh, Fernando J Duran, \\ Benjamin Darses, Philippe Dauban
}

\section{To cite this version:}

Ali Nasrallah, Gwendal Grelier, Maria Ivana Lapuh, Fernando J Duran, Benjamin Darses, et al.. Dirhodium(II)-Mediated Alkene Epoxidation with Iodine(III) Oxidants. European Journal of Organic Chemistry, 2018, 2018 (42), pp.5836-5842. 10.1002/ejoc.201800306 . hal-02366218

\section{HAL Id: hal-02366218 https://hal.science/hal-02366218}

Submitted on 15 Nov 2019

HAL is a multi-disciplinary open access archive for the deposit and dissemination of scientific research documents, whether they are published or not. The documents may come from teaching and research institutions in France or abroad, or from public or private research centers.
L'archive ouverte pluridisciplinaire HAL, est destinée au dépôt et à la diffusion de documents scientifiques de niveau recherche, publiés ou non, émanant des établissements d'enseignement et de recherche français ou étrangers, des laboratoires publics ou privés. 


\title{
Dirhodium(II)-mediated alkene epoxidation with iodine(III) oxidants
}

\author{
Ali Nasrallah, ${ }^{[\mathrm{a}]}$ Gwendal Grelier, ${ }^{[\mathrm{a}]}$ Maria Ivana Lapuh, ${ }^{[\mathrm{a}, \mathrm{b}]}$ Fernando J. Duran, ${ }^{[\mathrm{b}]}$ Benjamin Darses, ${ }^{[\mathrm{a}]}$ and \\ Philippe Dauban*[a]
}

To the memory of Pierre Potier

\begin{abstract}
Dirhodium(II) complexes and iodine(III) oxidants have found useful applications in synthetic nitrene chemistry. In this study, the combination of the dirhodium(II) complex $\mathrm{Rh}_{2}(\mathrm{tpa})_{4}$ with the iodine(III) oxidant Phl(OPiv) ${ }_{2}$ is shown to promote the epoxidation of alkenes in the presence of 2 equivalents of water. The reaction can be applied to diversely substituted alkenes and the corresponding epoxides are isolated with yields of up to $90 \%$. A possible mechanism would involve the dirhodium(II) complex as a Lewis acid species that would tune the oxidizing character of the iodine(III) reagent.
\end{abstract}

\section{Introduction}

Hypervalent iodine compounds are useful reagents in organic synthesis that allow for performing different types of oxidation reactions under mild conditions. ${ }^{[1,2]}$ Among the functional groups likely to react with iodine(III) oxidants, alkenes are valuable platforms that give generally access to a wide range of difunctionalized products. ${ }^{[3]}$ Epoxides, however, can also be obtained by the reaction of iodosylbenzene $(\mathrm{Phl}=0)$ with electron-deficient olefins such as enones and ketenes. ${ }^{[4]}$ Similarly, $\mathrm{Fe}(\mathrm{III})-, \mathrm{Mn}(\mathrm{III})-, \mathrm{Cr}(\mathrm{III})-$, Ru(II)- or Ru(III)-complexes inspired by the natural oxygenases, can react with $\mathrm{Phl}=\mathrm{O}$ to generate metal-oxo species that are highly efficient agents for the epoxidation of simple alkenes. ${ }^{[1,5]}$

Use of dirhodium(II) paddlewheel complexes for the decomposition of diazo compounds has led to significant breakthroughs in synthetic carbene chemistry. ${ }^{[6]}$ By comparison, their ability to mediate selective oxidation reactions has been less explored although this reactivity was first unveiled in $1982 .{ }^{[7]}$ Recent studies, nevertheless, have described efficient allylic and benzylic oxidations resulting from the reaction of a rhodium(II) complex with an oxidant such as tert-butylhydroperoxide. ${ }^{[8]}$ Dirhodium caprolactame, particularly, has proved highly active to mediate these reactions that proceed through a radical pathway. The mechanistic investigations, then, has led to develop a

[a] A. Nasrallah, G. Grelier, M. I. Lapuh, Dr. B. Darses, Dr. P. Dauban Institut de Chimie des Substances Naturelles, CNRS UPR 2301, Univ. Paris-Sud, Université Paris-Saclay, 1, av. de la Terrasse, 91198 Gif-sur-Yvette (France) E-mail: philippe.dauban@cnrs.fr

[b] M. I. Lapuh, Prof. F. J. Duran

Departamento de Quimica Organica and UMYMFOR (CONICETUBA), Facultad de Ciencias Exactas y Naturales, Universidad de Buenos Aires, Buenos Aires (Argentina)

Supporting information for this article is given via a link at the end of the document.
rhodium(II)-catalyzed alkene epoxidation under oxygen in the presence of isobutyraldehyde. ${ }^{[9]}$

The combination of the hypervalent iodine chemistry with the dirhodium(II) catalysis has been translated by several achievements in synthetic carbene ${ }^{[10]}$ and nitrene ${ }^{[11]}$ chemistry. Of particular relevance is the ability of dirhodium complexes to react with an iminoiodinane to afford a metallanitrene species. The latter allows for functionalizing different types of $\mathrm{C}\left(\mathrm{sp}^{3}\right)-\mathrm{H}$ bond and alkenes, ${ }^{[12]}$ thereby making the dirhodium(II)-catalyzed oxidative amination reactions new efficient tools for the synthesis of nitrogen-containing natural products and bioactive compounds (Scheme 1a). ${ }^{[13]}$

Recent investigations in our group, however, have revealed a different reactivity following the mixing of a dirhodium(II) complex and an iodine(III) oxidant. Application of reaction conditions likely to promote nitrene transfers to alkenes, thus, led us to isolate an epoxide instead of the expected aziridine (Scheme 1b). This unusual result convinced us to study further this transformation akin to a dirhodium(II)-assisted alkene epoxidation involving a trivalent iodine reagent. We, therefore, wish to report in this manuscript the results of our investigations.

\section{Previous studies}

a) Dirhodium(II)-catalyzed nitrene transfers with iodine(III) oxidants ${ }^{[2]}$

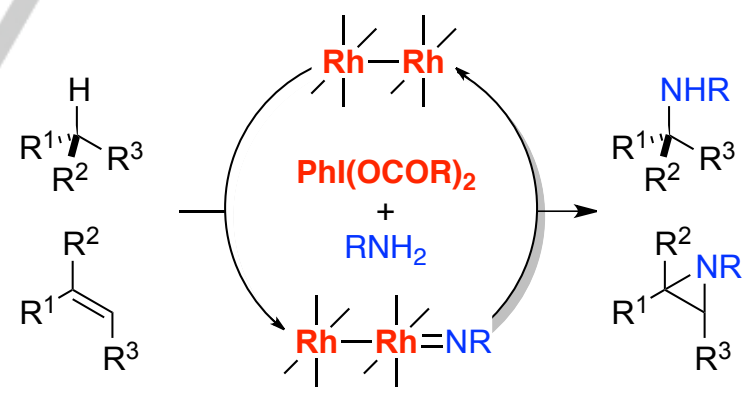

This work

b) Dirhodium(II)-assisted alkene epoxidation with iodine(III) oxidants

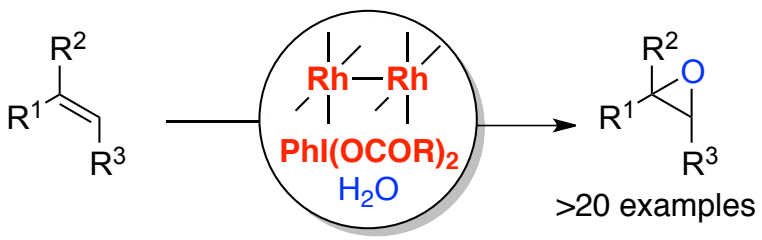

Scheme 1. Background for the study. 


\section{Results and Discussion}

\begin{tabular}{|c|c|c|c|c|}
\hline \multirow[b]{2}{*}{ Entry } & \multirow{2}{*}{$\frac{1 \mathrm{a}}{\text { Equiv. } \mathrm{H}_{2} \mathrm{O}}$} & \multicolumn{2}{|c|}{$\underset{\begin{array}{c}\text { cat. } \mathrm{Rh}_{2} \mathrm{~L}_{4} \\
\text { solvent }(\mathrm{c}=0.15 \mathrm{M}), 16 \mathrm{~h}\end{array}}{\mathrm{x} \text { equiv. } \mathrm{H}_{2} \mathrm{O}}$} & \multirow[b]{2}{*}{ Yield ${ }^{[a]}$} \\
\hline & & Catalyst (mol-\%) & Solvent & \\
\hline 1 & 0 & $\mathrm{Rh}_{2}(\mathrm{tpa})_{4}(2)$ & DCM & $<5$ \\
\hline 2 & 2 & $\mathrm{Rh}_{2}(\mathrm{tpa})_{4}(2)$ & DCM & 72 \\
\hline 3 & 2 & $\mathrm{Rh}_{2}(\mathrm{tpa})_{4}(2)$ & Trifluoroethanol & 83 \\
\hline 4 & 1 & $\mathrm{Rh}_{2}(\mathrm{tpa})_{4}(2)$ & Trifluoroethanol & 52 \\
\hline 5 & 4 & $\mathrm{Rh}_{2}(\mathrm{tpa})_{4}(2)$ & Trifluoroethanol & 83 \\
\hline 6 & 2 & $\mathrm{Rh}_{2}\left(\mathrm{OCOC}_{3} \mathrm{~F}_{7}\right)_{4}(2)$ & Trifluoroethanol & 40 \\
\hline 7 & 2 & $\mathrm{Rh}_{2}\left(\mathrm{OCOC}_{7} \mathrm{H}_{15}\right)_{4}(2)$ & Trifluoroethanol & 50 \\
\hline 8 & 2 & $\mathrm{Rh}_{2}(\mathrm{OAc})_{4}(2)$ & Trifluoroethanol & $<10$ \\
\hline 9 & 2 & $\mathrm{Rh}_{2}(\mathrm{esp})_{2}(2)$ & Trifluoroethanol & 60 \\
\hline 10 & 2 & $\mathrm{Rh}_{2}(\mathrm{tpa})_{4}(0.5)$ & Trifluoroethanol & 81 \\
\hline 11 & 2 & $\mathrm{Rh}_{2}(\mathrm{tpa})_{4}(\mathbf{0 . 1})$ & Trifluoroethanol & 40 \\
\hline $12^{[\mathrm{b}]}$ & 2 & $\mathrm{Rh}_{2}(\mathrm{tpa})_{4}(0.5)$ & Trifluoroethanol & 81 \\
\hline $13^{[\mathrm{c}]}$ & 2 & $\mathrm{Rh}_{2}(\mathrm{tpa})_{4}(0.5)$ & Trifluoroethanol & 78 \\
\hline
\end{tabular}

[a] Isolated yields. [b] The reaction was performed with 1.2 equivalents of $\mathrm{Phl}(\mathrm{OPiv})_{2}$. [c] With 1.2 equivalents of $\mathrm{Phl}(\mathrm{OAc})_{2}$

In the course of our studies devoted to the search for new efficient oxidative amination processes, we have found that the reaction of geranyl acetate $1 \mathrm{a}$ with a sulfamate and $\mathrm{Phl}(\mathrm{OPiv})_{2}$ (OPiv $=$ OCOtBu) in the presence of the $\mathrm{Rh}_{2}(\mathrm{esp})_{2}$ complex (esp $=\alpha, \alpha, \alpha^{\prime}, \alpha^{\prime}$-tetramethyl-1,3-benzenedipropionic acid $)^{[14]}$ affords a single product for which the NMR data clearly indicate the absence of the $\mathrm{SO}_{3} \mathrm{R}$ motif. Careful analysis of the NMR and MS spectra, thus, revealed that the isolated compound was the terminal tri-substituted epoxide $\mathbf{2 a}$. $^{[15]}$ The formation of such an oxygenated product under the classical conditions for nitrene addition was puzzling and led us to explore further the reaction. A first rapid screening of the reaction parameters in the absence of the nitrene precursor has shown that the best yields are obtained with the $\mathrm{Rh}_{2}(\mathrm{tpa})_{4}$ complex (tpa = triphenylacetate) as the catalyst in dichloromethane or trifluoroethanol (see Table S1 in supporting information). However, we have rapidly observed that the results strongly depend on the quality of the solvents with the presence of water being crucial for the course of the epoxidation reaction. Thus, whereas use of freshly distilled dichloromethane only leads to traces of $2 a$ (entry 1 , Table 1 ), the addition of 2 equivalents of water allows for improving the conversion, the epoxide $2 a$ being obtained with a yield of $72 \%$ (entry 2).
Table 2. Dirhodium-mediated epoxidation of tri-substituted alkenes. ${ }^{[a]}$

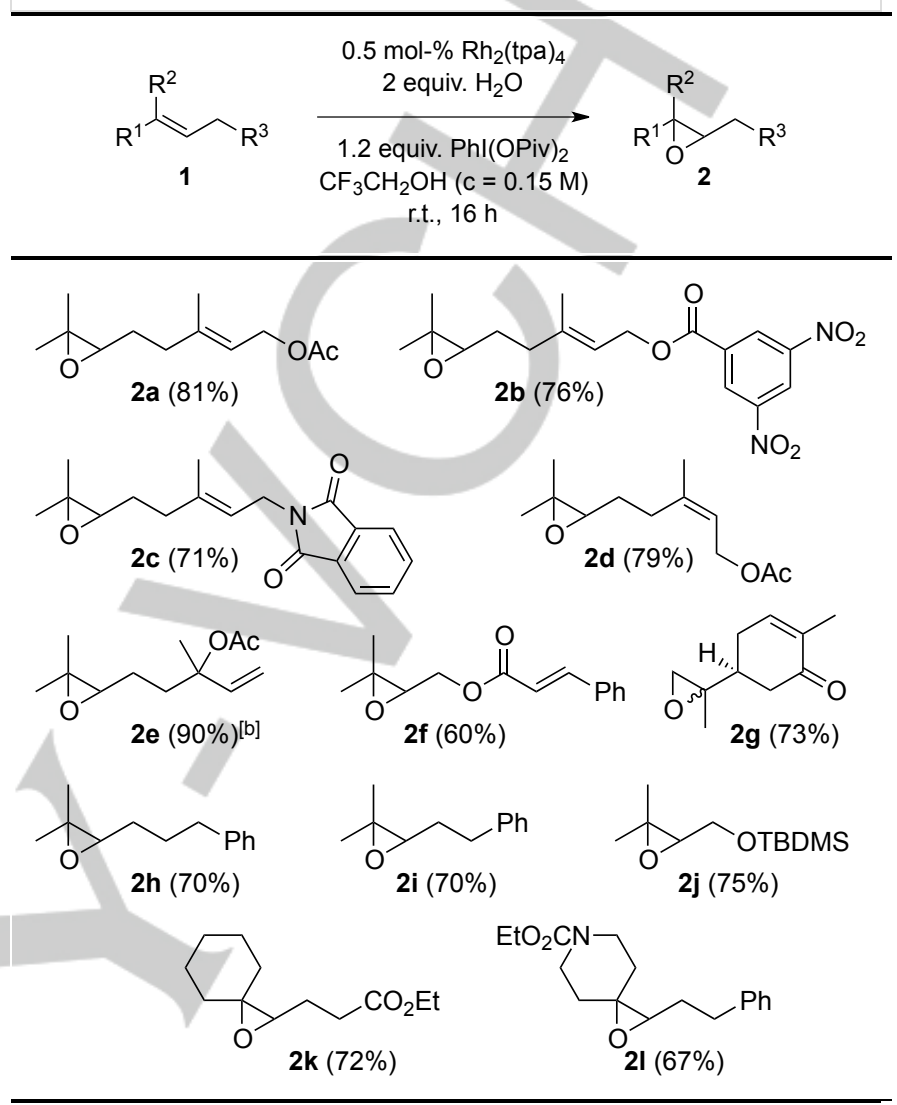

[a] Isolated yields. [b] $3 \mathrm{~h}$ of reaction.

The same observation was made with trifluoroethanol and the study performed with this solvent and 2 equivalents of $\mathrm{H}_{2} \mathrm{O}$ led to an optimized yield of $83 \%$ (entries $3-5$ ). Screening of the dirhodium(II) complexes again brings to light the highest activity of $\mathrm{Rh}_{2}(\mathrm{tpa})_{4}$ to mediate the epoxidation reaction (entries 6-9), a yield of $81 \%$ being obtained using only $0.5 \mathrm{~mol}-\%$ of this complex (entries 10 and 11). Finally, reducing the quantity of the iodine(III) oxidant to 1.2 equivalents does not modify the yield, as does the replacement of $\mathrm{Phl}(\mathrm{OPiv})_{2}$ by $\mathrm{Phl}(\mathrm{OAc})_{2}$ (entries 12 and 13). We have thus decided to choose the conditions displayed in entry 12 to explore the scope of the reaction. ${ }^{[16]}$

We first studied the case of tri-substituted alkenes (Table 2). ${ }^{[17]}$ Various geranyl and neryl derivatives proved to react efficiently to afford selectively the corresponding mono-epoxides $\mathbf{2 a - d}$, with yields between 71 and $81 \% .{ }^{[18]}$ The selectivity probably arises from the inductive effect of the terminal carboxylate or imide that decreases the reactivity of the proximal alkene. The epoxide $\mathbf{2 e}$ derived from linalyl acetate, on the other hand, highlights the higher reactivity of a tri-substituted olefin in the presence of a mono-substituted alkene. Similarly, epoxides $\mathbf{2 f}$ and $\mathbf{2 g}$ demonstrates that $\alpha, \beta$-unsaturated ester and ketone do not react under these conditions ${ }^{[19]}$ Substrates $\mathbf{1 h}$ and $\mathbf{1 i}$, which display a potentially oxidizable benzylic position, only led to the epoxides $\mathbf{2 h}$ and $\mathbf{2} \mathbf{i}$. Compound $\mathbf{2 j}$ shows the tolerance of the reaction 
towards the presence of a silyl-protecting group. Finally, spiro derivatives $\mathbf{2} \mathbf{k}$ and $\mathbf{2} \mathbf{I}$ can also be obtained from cyclic alkylidene starting materials.

Table 3. Dirhodium-mediated epoxidation of di-substituted alkenes. ${ }^{[a]}$

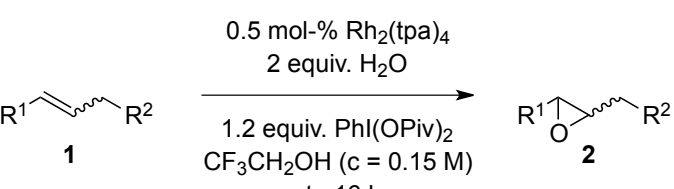

$$
\begin{aligned}
& \text { r.t., } 16 \mathrm{~h}
\end{aligned}
$$

dirhodium(II) complex only led to traces of the corresponding epoxide $\mathbf{2 a}$, thereby demonstrating its key role in the process.

The extensive mechanistic studies on the rhodium-catalyzed aerobic Mukaiyama epoxidation performed by Doyle, then, led us to consider the possible involvement of radicals. ${ }^{[9]}$ The reaction of 2-methyl-5-phenylpent-2-ene 1 i carried out with carefully degassed trifluoroethanol affords the epoxide $\mathbf{2} i$ with a similar yield, whereas the reaction of geranyl acetate in the presence of the radical inhibitor BHT allowed us for obtaining $\mathbf{2 a}$ without a noticeable change in the conversion. The hypothesis of a radical pathway was thus ruled out based on these observations.

The formation of metal-oxo species as those reported with $\mathrm{Fe}$, $\mathrm{Mn}, \mathrm{Cr}$ or $\mathrm{Ru}$ complexes, ${ }^{[5]}$ is unknown with dirhodium(II) complexes to the best of our knowledge. We, therefore, propose that the latter might act as a Lewis acid species in the alkene epoxidation according to the mechanism depicted in scheme $3^{[22,23,24]}$

The presence of water could induce a first ligand exchange with the $\mathrm{Phl}(\mathrm{OPiv})_{2}$ reagent to afford the iodine(III) species $\mathbf{A}$. Then, by analogy with the acknowledged mechanism of rhodiumcatalyzed nitrene transfer with iminoiodinanes, ${ }^{[12]}$ we suggest that the dirhodium(II) complex react with $\mathbf{A}$ to afford the intermediate of type $\mathbf{B}$. The latter could react with a double bond to produce the cyclic iodonium $\mathbf{C}^{[25]}$ that could undergo sequential nucleophilic displacement with water to give the epoxide 2, and release iodobenzene and water as by-products while regenerating the dirhodium(II) complex. This mechanistic hypothesis is in line with the lack of reactivity observed with poorly nucleophilic alkenes such as mono-substituted terminal olefins that could not add to the iodonium B. On the other hand, the isomerization observed in the case of compounds $2 n$ and $2 p$ could be rationalized by a hypothetical equilibrium between the intermediate $\mathbf{C}$ and the carbocationic species $\mathbf{D}$ that has been invoked in our previous study on alkene difunctionalization with rhodium-bound nitrenes. ${ }^{[12 \mathrm{~m}]}$ 3-en-1-ol do not react, aromatic alkenes can be converted to epoxides. Styrene derivatives substituted by a cyano or an ester function, thus, afford the corresponding epoxides in good yields (Scheme 2). ${ }^{[20]}$ However, the reaction with styrene as well as with $\alpha$ - or $\beta$-substituted derivatives led to the formation of an intractable mixture of products probably resulting from the oxidative cleavage of the epoxide. ${ }^{[21]}$

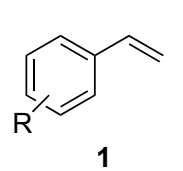

1

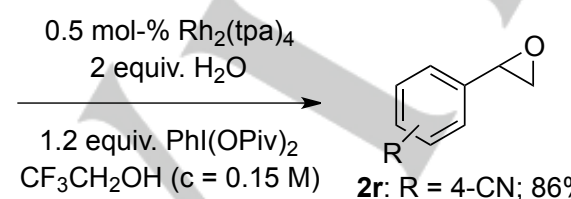

$\mathrm{CF}_{3} \mathrm{CH}_{2} \mathrm{OH}(\mathrm{c}=0.15 \mathrm{M}) \quad 2 \mathrm{r}: \mathrm{R}=4-\mathrm{CN} ; 86 \%$ r.t., $16 \mathrm{~h}$

2s: $\mathrm{R}=2-\mathrm{CN} ; 80 \%$

2t: $\mathrm{R}=4-\mathrm{CO}_{2} \mathrm{Me} ; 76 \%$
Scheme 2. Dirhodium-mediated epoxidation of styrene derivatives.

Several test experiments have been made to investigate the possible mechanism for this transformation. First, the reaction performed from geranyl acetate in the absence of the

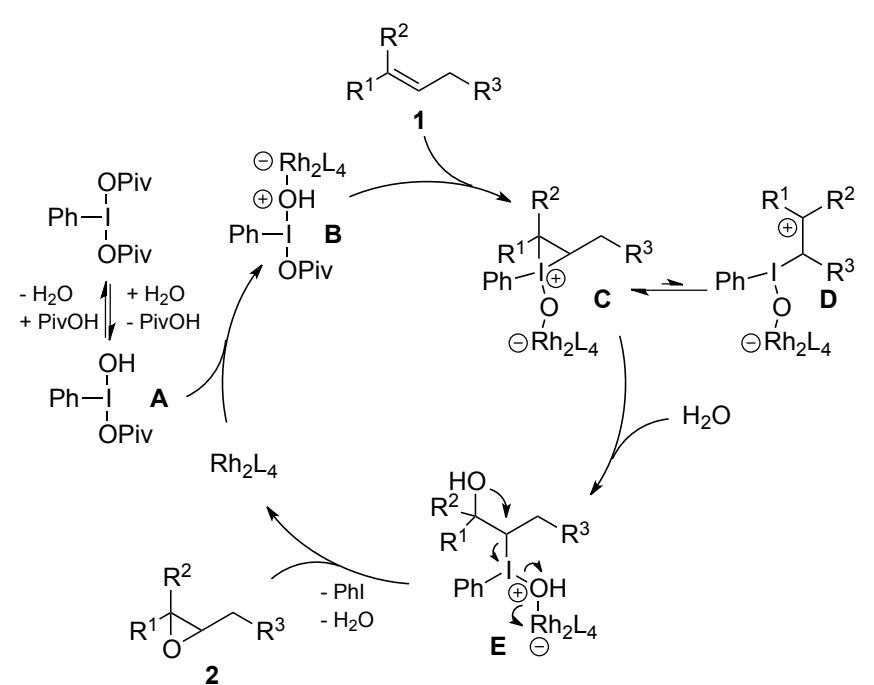

Scheme 3. Mechanism for the dirhodium-mediated epoxidation of alkene. 


\section{Conclusions}

This manuscript has documented an unusual reactivity arising from the combination of dirhodium(II) catalysts and iodine(III) oxidants. In the presence of a stoichiometric amount of an alkene and two equivalents of water, the reaction gives rise to epoxides that have been isolated with yields in the $60-90 \%$ range. Accordingly, this method could provide an alternative to classical methods for epoxidation involving, for example, the use of $m$-CPBA. The transformation applies to tri-, di-, and monosubstituted alkenes that display a nucleophilic character. Since this unusual reactivity was initially noticed under conditions for catalytic nitrene additions, it should be considered as a possible side reaction in further studies centered on allylic amination or alkene aziridination.

\section{Experimental Section}

General Procedure for the Epoxidation Reaction: A flask containing the substrate $\left(200 \mu \mathrm{mol}, 1.00\right.$ eq.) was charged with $\mathrm{Rh}_{2}(\mathrm{tpa})_{4}(1.40 \mathrm{mg}$, $1.00 \mu \mathrm{mol}, 0.5 \mathrm{~mol}-\%$ ) and $1.30 \mathrm{~mL}$ of 2,2,2-trifluoroethanol. To this mixture were added $\mathrm{Phl}(\mathrm{OPiv})_{2}(97.5 \mathrm{mg}, 240 \mu \mathrm{mol}, 1.20$ eq.) in one portion, and, then, $\mathrm{H}_{2} \mathrm{O}(7.20 \mu \mathrm{L}, 400 \mu \mathrm{mol}, 2.00$ eq.). The mixture was stirred between 4 and $16 \mathrm{~h}$ at room temperature. After concentration under reduced pressure, the residue was purified by flash chromatography on silica gel.

(E)-5-(3,3-Dimethyloxiran-2-yl)-3-methylpent-2-en-1-yl acetate (2a):[26] Prepared according to the general procedure for epoxidation using 1a (39.2 $\mathrm{mg}, 200 \mu \mathrm{mol}$ ) as the starting material. After purification by flash chromatography on silica gel (9/01 petroleum ether/AcOEt), 2a was obtained as a colorless oil (35.2 mg, $81 \%)$. The ${ }^{1} \mathrm{H}$ NMR spectrum is in accordance with the literature. ${ }^{1} \mathrm{H}$ NMR $\left(500 \mathrm{MHz} \mathrm{CDCl}_{3}\right) \delta 5.39(\mathrm{t}, \mathrm{J}=$ $6.8 \mathrm{~Hz}, 1 \mathrm{H}), 4.59(\mathrm{~d}, J=6.8 \mathrm{~Hz}, 2 \mathrm{H}), 2.70(\mathrm{t}, J=6.0 \mathrm{~Hz}, 1 \mathrm{H}), 2.30-2.10$ $(\mathrm{m}, 2 \mathrm{H}), 2.05(\mathrm{~s}, 3 \mathrm{H}), 1.73(\mathrm{~s}, 3 \mathrm{H}), 1.70-1.63(\mathrm{~m}, 2 \mathrm{H}), 1.31(\mathrm{~s}, 3 \mathrm{H}), 1.26$ (s, 3H) ppm. ${ }^{13} \mathrm{C}$ NMR $\left(75 \mathrm{MHz}, \mathrm{CDCl}_{3}\right) \delta 171.2,141.4,119.0,64.0,61.3$ $58.5,36.3,27.1,24.9,21.1,18.8,16.5 \mathrm{ppm}$

(E)-5-(3,3-Dimethyloxiran-2-yl)-3-methylpent-2-en-1-yl 3,5-dinitrobenzoate (2b): ${ }^{[27]}$ Prepared according to the general procedure for epoxidation using 1b $(69.0 \mathrm{mg}, 200 \mu \mathrm{mol})$ as the starting material. After purification by flash chromatography on silica gel (9:1 petroleum ether/AcOEt), $\mathbf{2 b}$ was obtained as a yellow solid $(55.0 \mathrm{mg}, 76 \%)$. The ${ }^{1} \mathrm{H}$ NMR spectrum is in accordance with the literature. ${ }^{1} \mathrm{H}$ NMR $(500 \mathrm{MHz}$, $\left.\mathrm{CDCl}_{3}\right) \delta 9.22(\mathrm{t}, J=2.1 \mathrm{~Hz}, 1 \mathrm{H}), 9.16(\mathrm{~d}, J=2.1 \mathrm{~Hz}, 2 \mathrm{H}), 5.57-5.52(\mathrm{~m}$ $1 \mathrm{H}), 4.98(\mathrm{~d}, J=7.3 \mathrm{~Hz}, 2 \mathrm{H}), 2.72(\mathrm{dd}, J=6.9,5.5 \mathrm{~Hz}, 1 \mathrm{H}), 2.34-2.19$ (m, 2H), $1.84(\mathrm{~s}, 3 \mathrm{H}), 1.77-1.64(\mathrm{~m}, 2 \mathrm{H}), 1.31$ (s, 3H), $1.28(\mathrm{~s}, 3 \mathrm{H}) \mathrm{ppm}$. ${ }^{13} \mathrm{C}$ NMR $\left(75 \mathrm{MHz}, \mathrm{CDCl}_{3}\right) \delta 162.7,148.8(2 \mathrm{C}), 143.7,134.3,129.6(2 \mathrm{C})$, $122.4,117.8,63.9,63.7,58.5,36.5,27.2,25.0,18.9,16.8 \mathrm{ppm}$.

(E)-2-(5-(3,3-Dimethyloxiran-2-yl)-3-methylpent-2-en-1-yl)isoindoline1,3-dione (2c)::28] Prepared according to the general procedure for epoxidation using $1 \mathrm{c}(57.0 \mathrm{mg}, 200 \mu \mathrm{mol})$ as the starting material. After purification by flash chromatography on silica gel (9:1 petroleum ether/AcOEt), 2c was obtained as white powder (42.0 mg, $70 \%)$. The ${ }^{1} \mathrm{H}$ NMR spectrum is in accordance with the literature. ${ }^{1} \mathrm{H}$ NMR $(300 \mathrm{MHz}$, $\left.\mathrm{CDCl}_{3}\right) \delta 7.88-7.80(\mathrm{~m}, 2 \mathrm{H}), 7.70(\mathrm{dd}, J=4.9,3.2 \mathrm{~Hz}, 2 \mathrm{H}), 5.31$ (t, $J=$ $7.0 \mathrm{~Hz}, 1 \mathrm{H}), 4.29(\mathrm{~d}, J=7.0 \mathrm{~Hz}, 2 \mathrm{H}), 2.67(\mathrm{t}, J=6.2 \mathrm{~Hz}, 1 \mathrm{H}), 2.26-2.05$ $(\mathrm{m}, 2 \mathrm{H}), 1.85(\mathrm{~s}, 3 \mathrm{H}), 1.69-1.57(\mathrm{~m}, 2 \mathrm{H}), 1.26(\mathrm{~s}, 3 \mathrm{H}), 1.24(\mathrm{~s}, 3 \mathrm{H}) \mathrm{ppm}$.
${ }^{13} \mathrm{C}$ NMR $\left(75 \mathrm{MHz}, \mathrm{CDCl}_{3}\right) \delta 168.2(2 \mathrm{C}), 139.9,134.0(2 \mathrm{C}), 132.4(2 \mathrm{C})$ $123.3(2 \mathrm{C}), 118.8,64.0,58.5,36.3,35.9,27.2,24.9,18.8,16.5 \mathrm{ppm}$.

(Z)-5-(3,3-Dimethyloxiran-2-yl)-3-methylpent-2-en-1-yl acetate (2d): [29] Prepared according to the general procedure for epoxidation using nerol acetate $(39.2 \mathrm{mg}, 200 \mu \mathrm{mol})$ as the starting material. After purification by flash chromatography on silica gel (9/01 petroleum ether/AcOEt), $2 \mathbf{d}$ was obtained as a colorless oil (35.2 $\mathrm{mg}, 79 \%)$. The ${ }^{1} \mathrm{H}$ NMR spectrum is in accordance with the literature. ${ }^{1} \mathrm{H}$ NMR $\left(300 \mathrm{MHz} \mathrm{CDCl}_{3}\right) \delta 5.41(\mathrm{t}, \mathrm{J}=$ $7.1 \mathrm{~Hz}, 1 \mathrm{H}), 4.59(\mathrm{~d}, J=7.1 \mathrm{~Hz}, 2 \mathrm{H}), 2.71(\mathrm{t}, J=6.2 \mathrm{~Hz}, 1 \mathrm{H}), 2.32-2.20$ $(\mathrm{m}, 2 \mathrm{H}), 2.05(\mathrm{~s}, 3 \mathrm{H}), 1.79(\mathrm{~s}, 3 \mathrm{H}), 1.73-1.54(\mathrm{~m}, 2 \mathrm{H}), 1.31(\mathrm{~s}, 3 \mathrm{H}), 1.27$ (s, 3H) ppm. ${ }^{13} \mathrm{C}$ NMR $\left(75 \mathrm{MHz} \mathrm{CDCl}_{3}\right) \delta 171.2,141.8,119.9,73.9,61.0$, $58.5,29.0,27.7,25.0,23.6,21.2,18.8 \mathrm{ppm}$.

5-(3,3-Dimethyloxiran-2-yl)-3-methylpent-1-en-3-yl acetate $\quad(2 e):[9]$ Prepared according to the general procedure for epoxidation using $1 e$ $(39.2 \mathrm{mg}, 200 \mu \mathrm{mol})$ as the starting material. After purification by flash chromatography on silica gel (9:1 petroleum ether/AcOEt), $2 \mathbf{e}$ was obtained as a colorless oil (38.0 mg, $90 \%$ ). The ${ }^{1} \mathrm{H}$ NMR spectrum is in accordance with the literature. ${ }^{1} \mathrm{H}$ NMR $\left(300 \mathrm{MHz}, \mathrm{CDCl}_{3}\right) \delta 6.04-5.88$ $(\mathrm{m}, 1 \mathrm{H}), 5.25-5.07(\mathrm{~m}, 2 \mathrm{H}), 2.71(\mathrm{t}, J=6.2 \mathrm{~Hz}, 1 \mathrm{H}), 2.01(\mathrm{~s}, 3 \mathrm{H}), 1.95-$ $1.85(\mathrm{~m}, 2 \mathrm{H}), 1.55(\mathrm{~d}, J=6.9 \mathrm{~Hz}, 3 \mathrm{H}), 1.68-1.40(\mathrm{~m}, 2 \mathrm{H}), 1.31(\mathrm{~s}, 3 \mathrm{H})$, 1.25 (d, $J=5.3 \mathrm{~Hz}, 3 \mathrm{H}) \mathrm{ppm} .{ }^{13} \mathrm{C}$ NMR $\left(75 \mathrm{MHz} \mathrm{CDCl}_{3}\right) \delta 170.0,141.6$, $141.4,113.7,113.6,82.6,82.5,64.1,58.5,36.4,25.0,23.8,23.7,23.6$, 22.3, 18.7 ppm.

(3,3-Dimethyloxiran-2-yl)methyl cinnamate (2f): Prepared according to the general procedure for epoxidation using $1 \mathrm{f}(43.2 \mathrm{mg}, 200 \mu \mathrm{mol})$ as the starting material. After purification by flash chromatography on silica gel (9:1 petroleum ether/AcOEt) $\mathbf{2} \mathbf{f}$ was obtained as a colorless liquid (27.6 mg, $60 \%) .{ }^{1} \mathrm{H}$ NMR (300 MHz, $\left.\mathrm{CDCl}_{3}\right) \delta 7.77-7.70(\mathrm{~m}, 1 \mathrm{H}), 7.55$ - $7.51(\mathrm{~m}, 2 \mathrm{H}), 7.41-7.38(\mathrm{~m}, 3 \mathrm{H}), 6.48(\mathrm{~d}, J=16.1 \mathrm{~Hz}, 1 \mathrm{H}), 4.49(\mathrm{dd}, J$ $=12.1,4.2 \mathrm{~Hz}, 1 \mathrm{H}), 4.15(\mathrm{dd}, J=12.1,6.8 \mathrm{~Hz}, 1 \mathrm{H}), 3.11-3.05(\mathrm{~m}, 1 \mathrm{H})$, 1.38 (s, 3H), 1.37 (s, 3H) ppm. ${ }^{13} \mathrm{C}$ NMR (75 MHz, $\left.\mathrm{CDCl}_{3}\right) \delta$ 166.9, 145.6, 134.4, 130.5, 129.0 (2C), 128.3 (2C), 117.6, 63.6, 60.7, 58.2, 24.7, 19.1 ppm. IR(neat) $v=2962,2928,1712,1635,1526,1451,1351,1307$, $1254,1165,1133 \mathrm{~cm}^{-1}$. HRMS $=[\mathrm{M}+\mathrm{H}]^{+}$calculated for $\left[\mathrm{C}_{14} \mathrm{H}_{17} \mathrm{O}_{3}\right]^{+}=$ 233.1172, found 233.1176.

(R)-2-Methyl-5-((R)-2-methyloxiran-2-yl)cyclohex-2-en-1-one $\quad(2 \mathrm{~g}):{ }^{[30]}$ Prepared according to the general procedure for epoxidation using $(R)$ Carvone $(30.0 \mathrm{mg}, 200 \mu \mathrm{mol})$ as the starting material. After purification by flash chromatography on silica gel (9:1 petroleum ether/AcOEt), 5 was obtained as a yellow oil (24.1 mg, $73 \%)$. The ${ }^{1} \mathrm{H}$ NMR spectrum is in accordance with the literature. ${ }^{1} \mathrm{H}$ NMR $\left(300 \mathrm{MHz}, \mathrm{CDCl}_{3}\right) \delta 6.74(\mathrm{~s}, 1 \mathrm{H})$, 2.69 (dd, $J=11.0,4.5 \mathrm{~Hz}, 1 \mathrm{H}), 2.63-2.57(\mathrm{~m}, 2 \mathrm{H}), 2.50-2.33(\mathrm{~m}, 2 \mathrm{H})$, $2.33-2.14(\mathrm{~m}, 2 \mathrm{H}), 1.78(\mathrm{~s}, 3 \mathrm{H}), 1.32(\mathrm{~d}, J=5.0 \mathrm{~Hz}, 3 \mathrm{H}) \mathrm{ppm} .{ }^{13} \mathrm{C}$ NMR $\left(75 \mathrm{MHz}, \mathrm{CDCl}_{3}\right) \delta 199.0,144.3,144.0,135.7,58.1,58.0,53.1,52.5$, $41.5,40.8,40.5,40.1,28.0,27.8,19.2,18.5,15.8 \mathrm{ppm}$

2,2-Dimethyl-3-(3-phenylpropyl)oxirane (2h): Prepared according to the general procedure for epoxidation using $1 \mathrm{~h}(35.0 \mathrm{mg}, 200 \mu \mathrm{mol})$ as the starting material. After purification by flash chromatography on silica gel (9.5:0.5 petroleum ether/AcOEt), $\mathbf{2} \mathbf{h}$ was obtained as colorless liquid (26.0 mg, $70 \%) .{ }^{1} \mathrm{H} \mathrm{NMR}\left(300 \mathrm{MHz}, \mathrm{CDCl}_{3}\right) \delta 7.30-7.25(\mathrm{~m}, 3 \mathrm{H}), 7.19$ (d, $J=6.6 \mathrm{~Hz}, 2 \mathrm{H}), 2.74(\mathrm{dd}, J=11.4,5.0 \mathrm{~Hz}, 1 \mathrm{H}), 2.70-2.63(\mathrm{~m}, 2 \mathrm{H}), 1.93$ $-1.66(\mathrm{~m}, 2 \mathrm{H}), 1.62-1.52(\mathrm{~m}, 2 \mathrm{H}), 1.30(\mathrm{~s}, 3 \mathrm{H}), 1.24(\mathrm{~s}, 3 \mathrm{H}) \mathrm{ppm} .{ }^{13} \mathrm{C}$ NMR $\left(75 \mathrm{MHz}, \mathrm{CDCl}_{3}\right) \delta 142.2,128.5(2 \mathrm{C}), 128.4(2 \mathrm{C}), 125.9,64.4$, $58.3135 .8,28.6,28.5,25.0,18.8 \mathrm{ppm}$. IR(neat) $v=2959,2921,2860$, $1496,1455,1376,1283,1249,1153,1114,890,745,697 \mathrm{~cm}^{-1}$. HRMS = $[\mathrm{M}+\mathrm{H}]^{+}$calculated for $\left[\mathrm{C}_{13} \mathrm{H}_{19} \mathrm{O}\right]^{+}=191.1430$, found 191.1442 . 
2,2-Dimethyl-3-phenethyloxirane (2i):[31] Prepared according to the general procedure for epoxidation using $1 \mathrm{i}(32.0 \mathrm{mg}, 200 \mu \mathrm{mol})$ as the starting material. After purification by flash chromatography on silica gel (9:1 petroleum ether/AcOEt), $\mathbf{2} \mathbf{i}$ was obtained as a white solid $(25.0 \mathrm{mg}$, $72 \%$ ). The ${ }^{1} \mathrm{H}$ NMR spectrum is in accordance with the literature. ${ }^{1} \mathrm{H}$ NMR (300 MHz, $\left.\mathrm{CDCl}_{3}\right) \delta 7.28(\mathrm{~m}, 3 \mathrm{H}), 7.20(\mathrm{~d}, J=6.0 \mathrm{~Hz}, 2 \mathrm{H}), 2.92$ $2.64(\mathrm{~m}, 3 \mathrm{H}), 1.99-1.73(\mathrm{~m}, 2 \mathrm{H}), 1.27(\mathrm{~s}, 3 \mathrm{H}), 1.12(\mathrm{~s}, 3 \mathrm{H}) \mathrm{ppm} .{ }^{13} \mathrm{C}$ NMR (75 MHz, $\left.\mathrm{CDCl}_{3}\right) \delta 141.6,128.6$ (2C), 128.5 (2C), 126.2, 64.0, 58.7, 32.9, 30.9, 24.9, $18.7 \mathrm{ppm}$.

tert-Butyl((3,3-dimethyloxiran-2-yl)methoxy)dimethylsilane $\quad(2 \mathbf{j}):^{[32]}$ Prepared according to the general procedure for epoxidation using $1 \mathbf{j}$ $(40.0 \mathrm{mg}, 200 \mu \mathrm{mol})$ as the starting material. After purification by flash chromatography on silica gel (9.5:0.5 petroleum ether/AcOEt), 2j was obtained as a colorless oil $(32.4 \mathrm{mg}, 75 \%)$. The ${ }^{1} \mathrm{H}$ NMR spectrum is in accordance with the literature. ${ }^{1} \mathrm{H}$ NMR $\left(300 \mathrm{MHz}, \mathrm{CDCl}_{3}\right) \delta 3.74(\mathrm{~d}, \mathrm{~J}=$ $5.3 \mathrm{~Hz}, 2 \mathrm{H}), 2.90(\mathrm{t}, J=5.3 \mathrm{~Hz}, 1 \mathrm{H}), 1.34(\mathrm{~s}, 3 \mathrm{H}), 1.28(\mathrm{~s}, 3 \mathrm{H}), 0.91$ (s, $9 \mathrm{H}), 0.09$ (s, 3H), 0.08 (s, 3H) ppm. ${ }^{13} \mathrm{C}$ NMR $\left(75 \mathrm{MHz}, \mathrm{CDCl}_{3}\right) \delta 64.2$, $62.5,58.3,26.0(3 \mathrm{C}), 25.0(2 \mathrm{C}), 19.0,-5.0,-5.2 \mathrm{ppm}$

Ethyl 3-(1-oxaspiro[2.5]octan-2-yl)propanoate (2k): Prepared according to the general procedure for epoxidation using $\mathbf{1 k}(39.3 \mathrm{mg}$ $200 \mu \mathrm{mol}$ ) as the starting material. After purification by flash chromatography on silica gel (9:1 petroleum ether/AcOEt), $2 \mathbf{k}$ was obtained as a colorless oil $(30.0 \mathrm{mg}, 71 \%) .{ }^{1} \mathrm{H} \mathrm{NMR}\left(300 \mathrm{MHz}, \mathrm{CDCl}_{3}\right) \delta$ $4.15(\mathrm{q}, J=7.1 \mathrm{~Hz}, 2 \mathrm{H}), 2.80-2.72(\mathrm{~m}, 1 \mathrm{H}), 2.48(\mathrm{dd}, J=11.8,7.6 \mathrm{~Hz}$ 2H), $2.00-1.63(\mathrm{~m}, 4 \mathrm{H}), 1.62-1.47(\mathrm{~m}, 8 \mathrm{H}), 1.26(\mathrm{t}, J=7.0 \mathrm{~Hz}, 3 \mathrm{H})$ ppm. ${ }^{13} \mathrm{C}$ NMR $\left(75 \mathrm{MHz}, \mathrm{CDCl}_{3}\right) \delta 173.6,60.5,51.3,43.1,32.2,31.7$, 29.5, 28.7, 27.4, $24.4(1 \mathrm{C}+1 \mathrm{C}), 14.4 \mathrm{ppm}$. IR(neat) $v=2928,2860$, $1736,169,1455,1375,1275,1169,1123,1031,934 \mathrm{~cm}^{-1} . \mathrm{HRMS}=$ $[\mathrm{M}+\mathrm{H}]^{+}$calculated for $\left[\mathrm{C}_{12} \mathrm{H}_{21} \mathrm{O}_{3}\right]^{+}=213.1485$, found 213.1471 .

Ethyl 2-phenethyl-1-oxa-6-azaspiro[2.5]octane-6-carboxylate (2I) Prepared according to the general procedure for epoxidation using 1 I $(55.0 \mathrm{mg}, 200 \mu \mathrm{mol})$ as the starting material. After purification by flash chromatography on silica gel (9:1 petroleum ether/AcOEt), 2l was obtained as a colorless oil (38.0 mg, $67 \%) .{ }^{1} \mathrm{H} \mathrm{NMR}\left(300 \mathrm{MHz}, \mathrm{CDCl}_{3}\right) \delta$ $7.34-7.25(\mathrm{~m}, 2 \mathrm{H}), 7.24-7.16(\mathrm{~m}, 3 \mathrm{H}), 4.14(\mathrm{q}, J=6.4 \mathrm{~Hz}, 2 \mathrm{H}), 3.82-$ $3.62(\mathrm{~m}, 2 \mathrm{H}), 3.44-3.26(\mathrm{~m}, 2 \mathrm{H}), 2.88-2.82(\mathrm{~m}, 2 \mathrm{H}), 2.80-2.65(\mathrm{~m}$, $1 \mathrm{H}), 2.02-1.67(\mathrm{~m}, 4 \mathrm{H}), 1.52-1.31(\mathrm{~m}, 2 \mathrm{H}), 1.26(\mathrm{t}, J=6.4 \mathrm{~Hz}, 3 \mathrm{H})$ ppm. ${ }^{13} \mathrm{C}$ NMR $\left(75 \mathrm{MHz} \mathrm{CDCl}_{3}\right) \delta 155.6,141.2,128.7(2 \mathrm{C}), 128.6(2 \mathrm{C})$ $126.4,63.9,61.5,61.1,42.2,42.3,34.6,32.8,30.0,29.0,14.8 \mathrm{ppm}$. $\operatorname{IR}$ (neat) $v=2962,2931,2863,1693,1428,1378,1275,1229,1169$ $1125,1093,1069,1026,890,764,749,698 \mathrm{~cm}^{-1}$. HRMS $=[\mathrm{M}+\mathrm{H}]^{+}$ calculated for $\left[\mathrm{C}_{17} \mathrm{H}_{24} \mathrm{NO}_{3}\right]^{+}=290.1750$, found 290.1780 .

4-Nitrobenzyl 2-(3-methyloxiran-2-yl)acetate $(\mathbf{2 m})$ : Prepared according to the general procedure for epoxidation using $1 \mathrm{~m}(47.0 \mathrm{mg}, 200 \mu \mathrm{mol})$ as the starting material. After purification by flash chromatography on silica gel (9:1 petroleum ether/AcOEt), $2 \mathrm{~m}$ was obtained as a colorless oil (35.5 mg, $71 \%$ ). ${ }^{1} \mathrm{H}$ NMR (500 MHz, $\left.\mathrm{CDCl}_{3}\right) \delta 8.23$ (d, $J=8.3 \mathrm{~Hz}, 2 \mathrm{H}$ ), $7.53(\mathrm{~d}, J=8.3 \mathrm{~Hz}, 2 \mathrm{H}), 5.26(\mathrm{~s}, 2 \mathrm{H}), 3.05(\mathrm{~d}, J=4.4 \mathrm{~Hz}, 1 \mathrm{H}), 2.89-$ $2.82(\mathrm{~m}, 1 \mathrm{H}), 2.65$ (ddd, $J=22.9,16.4,5.6 \mathrm{~Hz}, 2 \mathrm{H}), 1.34(\mathrm{~d}, J=5.0 \mathrm{~Hz}$, $3 \mathrm{H}) \mathrm{ppm} .{ }^{13} \mathrm{C}$ NMR $\left(75 \mathrm{MHz}, \mathrm{CDCl}_{3}\right) \delta 170.2,143.0,128.5(2 \mathrm{C}), 124.0$ (2C), 65.2, 54.8, 54.6, 37.7, 17.4 ppm. IR(neat) $v=2959,2921,2860$, $1550,1475,1455,1376,1283,1249,1153,1114,890,745 \mathrm{~cm}^{-1}$. HRMS $=[\mathrm{M}+\mathrm{H}]^{+}$calculated for $\left[\mathrm{C}_{12} \mathrm{H}_{14} \mathrm{NO}_{5}\right]^{+}=252.0876$, found 252.0866 .

(E)-3-(3-Methyloxiran-2-yl)allyl acetate (2n): [33] Prepared according to the general procedure for epoxidation using trans,trans-2,4-hexadienyl acetate $(28.0 \mathrm{mg}, 200 \mu \mathrm{mol})$ as the starting material. After purification by flash chromatography on silica gel (9.5:0.5 petroleum ether/AcOEt), 2n was obtained as a mixture of 10:1 trans:cis isomers, and as a colorless oil $(22.5 \mathrm{mg}, 72 \%)$. Only the major diastereoisomer is described for clarity. The ${ }^{1} \mathrm{H}$ NMR spectrum is in accordance with the literature. ${ }^{1} \mathrm{H}$ NMR (300 MHz, $\left.\mathrm{CDCl}_{3}\right) \delta 6.07-5.90(\mathrm{~m}, 1 \mathrm{H}), 5.51$ (dd, $J=15.4,7.9 \mathrm{~Hz}$, $1 \mathrm{H}), 4.58(\mathrm{~d}, J=5.9 \mathrm{~Hz}, 2 \mathrm{H}), 3.11(\mathrm{dd}, J=14.9,7.2 \mathrm{~Hz}, 1 \mathrm{H}), 2.92(\mathrm{~d}, J=$ $5.1 \mathrm{~Hz}, 1 \mathrm{H}), 2.08(\mathrm{~s}, 3 \mathrm{H}), 1.35(\mathrm{~d}, J=5.1 \mathrm{~Hz}, 3 \mathrm{H}) \mathrm{ppm} .{ }^{13} \mathrm{C}$ NMR $(75$ $\left.\mathrm{MHz}_{\mathrm{CDCl}}\right) \delta 171.6,132.0,128.8,64.0,58.6,56.7,21.0,17.6 \mathrm{ppm}$.

\section{$\left(3 R^{*}, 4 R^{*}\right)$-tert-Butyl(2-(3-ethyloxiran-2-yl)ethoxy)dimethylsilane}

(20):[34] Prepared according to the general procedure for epoxidation using $10(42.9 \mathrm{mg}, 200 \mu \mathrm{mol})$ as the starting material. After purification by flash chromatography on silica gel (9:1 petroleum ether/AcOEt), 20 was obtained as white powder $(32.7 \mathrm{mg}, 71 \%)$. The ${ }^{1} \mathrm{H}$ NMR spectrum is in accordance with the literature. ${ }^{1} \mathrm{H}$ NMR $\left(300 \mathrm{MHz}, \mathrm{CDCl}_{3}\right) \delta 3.75$ (dd, J $=6.3,6.0 \mathrm{~Hz}, 2 \mathrm{H}), 2.81(\mathrm{td}, J=6.0,2.4 \mathrm{~Hz}, 1 \mathrm{H}), 2.69(\mathrm{td}, J=5.4,2.4 \mathrm{~Hz}$, $1 \mathrm{H}), 1.82-1.63(\mathrm{dt}, J=12.9,6.6 \mathrm{~Hz}, 2 \mathrm{H}), 1.57(\mathrm{~m}, 2 \mathrm{H}), 1.07(\mathrm{t}, J=7.5 \mathrm{~Hz}$, $3 \mathrm{H}), 0.92(\mathrm{~s}, 9 \mathrm{H}), 0.09(\mathrm{~s}, 6 \mathrm{H}) \mathrm{ppm} .{ }^{13} \mathrm{C} \mathrm{NMR}\left(75 \mathrm{MHz}, \mathrm{CDCl}_{3}\right) \delta 60.2$ (2C), 56.2, 35.7, 26.0 (3C), 25.3, 18.4, 10.0, -5.2 (2C) ppm.

\section{$\left(3 R^{*}, 4 S^{*}\right)$-tert-Butyl(2-(3-ethyloxiran-2-yl)ethoxy)dimethylsilane}

$(2 p):[35]$ Prepared according to the general procedure for epoxidation using $1 \mathrm{p}(42.9 \mathrm{mg}, 200 \mu \mathrm{mol})$ as the starting material. After purification by flash chromatography on silica gel (9:1 petroleum ether/AcOEt), $\mathbf{2} \mathbf{p}$ was obtained as a mixture of $13: 1$ cis:trans isomers, and as a colorless liquid (32.7 mg, $71 \%$ ). Only the major diastereoisomer is described for clarity. The ${ }^{1} \mathrm{H}$ NMR spectrum is in accordance with the literature. ${ }^{1} \mathrm{H}$ NMR (500 MHz, $\left.\mathrm{CDCl}_{3}\right) \delta 3.81-3.77(\mathrm{~m}, 2 \mathrm{H}), 3.09-3.04(\mathrm{~m}, 1 \mathrm{H}), 2.93$ $-2.88(\mathrm{~m}, 1 \mathrm{H}), 1.84-1.74(\mathrm{~m}, 1 \mathrm{H}), 1.72-1.63(\mathrm{~m}, 1 \mathrm{H}), 1.61-1.47(\mathrm{~m}$, $2 \mathrm{H}), 1.05$ (t, $J=7.5 \mathrm{~Hz}, 3 \mathrm{H}), 0.90(\mathrm{~s}, 9 \mathrm{H}), 0.07$ (s, 6H) ppm. ${ }^{13} \mathrm{C}$ NMR $(75$ $\left.\mathrm{MHz}, \mathrm{CDCl}_{3}\right) \delta 60.7,58.4,54.9,31.3,26.0(3 \mathrm{C}), 21.4,18.5,10.7,-5.2$ (2C) $\mathrm{ppm}$

2-(2-Methyloxiran-2-yl)ethyl benzoate (2q). ${ }^{[36]}$ Prepared according to the general procedure for epoxidation using $1 \mathrm{q}(32.4 \mathrm{mg}, 200 \mu \mathrm{mol})$ as the starting material. After purification by flash chromatography on silica gel (9.5:0.5 petroleum ether/AcOEt), $2 q$ was obtained as brown powder (25.0 mg, $71 \%$ ). The ${ }^{1} \mathrm{H}$ NMR spectrum is in accordance with the literature. ${ }^{1} \mathrm{H}$ NMR $\left(300 \mathrm{MHz}, \mathrm{CDCl}_{3}\right) \delta 8.04(\mathrm{~d}, J=7.8 \mathrm{~Hz}, 2 \mathrm{H}), 7.57(\mathrm{t}, J$ $=7.1 \mathrm{~Hz}, 1 \mathrm{H}), 7.45(\mathrm{t}, J=7.7 \mathrm{~Hz}, 2 \mathrm{H}), 4.54-4.36(\mathrm{~m}, 2 \mathrm{H}), 2.72(\mathrm{~d}, J=$ $4.7 \mathrm{~Hz}, 1 \mathrm{H}), 2.64(\mathrm{~d}, J=4.7 \mathrm{~Hz}, 1 \mathrm{H}), 2.18-1.94(\mathrm{~m}, 2 \mathrm{H}), 1.42(\mathrm{~s}, 3 \mathrm{H})$ ppm. ${ }^{13} \mathrm{C}$ NMR $\left(75 \mathrm{MHz}, \mathrm{CDCl}_{3}\right) \delta 166.7,133.2,129.7$ (2C), 129.4, 128.6 (2C), 74.4, 61.6, 59.9, 35.9, $21.5 \mathrm{ppm}$.

4-(Oxiran-2-yl)benzonitrile (2r). ${ }^{[37]}$ Prepared according to the general procedure for epoxidation using $1 \mathrm{r}(28.8 \mathrm{mg}, 200 \mu \mathrm{mol})$ as the starting material. After purification by flash chromatography on silica gel (9.5:0.5 petroleum ether/AcOEt), $2 r$ was obtained as white powder $(24.5 \mathrm{mg}$, $85 \%)$. The ${ }^{1} \mathrm{H}$ NMR spectrum is in accordance with the literature. ${ }^{1} \mathrm{H}$ NMR (300 MHz, $\left.\mathrm{CDCl}_{3}\right) \delta 7.64(\mathrm{~d}, J=7.8 \mathrm{~Hz}, 2 \mathrm{H}), 7.39(\mathrm{~d}, J=7.8 \mathrm{~Hz}$, 2H), 3.91 (dd, $J=2.5,4.0 \mathrm{~Hz}, 1 \mathrm{H}), 3.21(\mathrm{dd}, J=5.4,4.2 \mathrm{~Hz}, 1 \mathrm{H}), 2.76$ (dd, $J=5.5,2.4 \mathrm{~Hz}, 1 \mathrm{H}) \mathrm{ppm} .{ }^{13} \mathrm{C}$ NMR $\left(75 \mathrm{MHz} \mathrm{CDCl}_{3}\right) \delta 144.0,132.5$ (2C), 126.3 (2C), 118.7, 112.1, 51.7 (2C) ppm.

2-(Oxiran-2-yl)benzonitrile (2s): ${ }^{[37]}$ Prepared according to the general procedure for epoxidation using $1 \mathrm{~s}(26.0 \mathrm{mg}, 200 \mu \mathrm{mol})$ as the starting material. After purification by flash chromatography on silica gel (9:1 petroleum ether/AcOEt), 2s was obtained as white powder $(23.0 \mathrm{mg}$, $80 \%)$. The ${ }^{1} \mathrm{H}$ NMR spectrum is in accordance with the literature. ${ }^{1} \mathrm{H}$ NMR $\left(300 \mathrm{MHz}, \mathrm{CDCl}_{3}\right) \delta 7.66(\mathrm{~d}, J=7.6 \mathrm{~Hz}, 1 \mathrm{H}), 7.60(\mathrm{t}, J=7.6 \mathrm{~Hz}$, $1 \mathrm{H}), 7.40(\mathrm{t}, J=7.6 \mathrm{~Hz}, 1 \mathrm{H}), 7.34(\mathrm{~d}, J=7.6 \mathrm{~Hz}, 1 \mathrm{H}), 4.25(\mathrm{~s}, 1 \mathrm{H}), 3.29$ $3.24(\mathrm{~m}, 1 \mathrm{H}), 2.78-2.73(\mathrm{~m}, 1 \mathrm{H}) \mathrm{ppm} .{ }^{13} \mathrm{C} \mathrm{NMR}\left(75 \mathrm{MHz}, \mathrm{CDCl}_{3}\right) \delta$ 133.5 (2C), 132.9 (2C), 128.6, 125.0, 101.8, 51.6, 50.5 ppm.

Methyl 4-(oxiran-2-yl)benzoate (2t): ${ }^{[38]}$ Prepared according to the general procedure for epoxidation using $1 \mathrm{t}(32.4 \mathrm{mg}, 200 \mu \mathrm{mol})$ as the 
starting material. After purification by flash chromatography on silica gel (9:1 petroleum ether/AcOEt), $\mathbf{2} \mathbf{t}$ was obtained as white powder $(27.0 \mathrm{mg}$, $76 \%$ ). The ${ }^{1} \mathrm{H}$ NMR spectrum is in accordance with the literature. ${ }^{1} \mathrm{H}$ NMR $\left(300 \mathrm{MHz}, \mathrm{CDCl}_{3}\right) \delta 8.05$ (d, $\left.J=7.7 \mathrm{~Hz}, 1 \mathrm{H}\right), 7.38(\mathrm{~d}, J=7.7 \mathrm{~Hz}$, $1 \mathrm{H}), 3.95(\mathrm{~s}, 4 \mathrm{H}), 3.25-3.19(\mathrm{~m}, 1 \mathrm{H}), 2.87-2.79(\mathrm{~m}, 1 \mathrm{H}) \mathrm{ppm} .{ }^{13} \mathrm{C}$ NMR $\left(75 \mathrm{MHz}, \mathrm{CDCl}_{3}\right) \delta 166.9,143.0,130.0(2 \mathrm{C}), 126.9,125.6(2 \mathrm{C})$, 52.3, 52.0, $51.6 \mathrm{ppm}$.

\section{Acknowledgements}

We wish to thank the French National Research Agency (program $n^{\circ}$ ANR-11-IDEX-0003-02, CHARMMMAT ANR-11LABX-0039, and ANR-15-CE29-0014-01; fellowship to A. N.), the Ministère de l'Enseignement Supérieur et de la Recherche (fellowship to G. G.), the Saint Exupery Program (grant to M. I. H.), the ECOS-Sud Committee (Action A15E04), and the Institut de Chimie des Substances Naturelles for their support.

Keywords: Hypervalent iodine $\cdot$ rhodium • epoxidation • alkene - Lewis acid

[1] For relevant general reviews, see: a) P. J. Stang, V. V. Zhdankin, Chem. Rev. 1996, 96, 1123; b) V. V. Zhdankin, P. J. Stang, Chem. Rev. 2002 102, 2523; c) V. V. Zhdankin, P. J. Stang, Chem. Rev. 2008, 108, 5299; d) A. Yoshimura, V. V. Zhdankin, Chem. Rev. 2016, 116, 3328; e) U. Ladziata, V. V. Zhdankin, Arkivoc 2006, ix, 26; e) V. V. Zhdankin, Arkivoc 2009, i, 1-62

[2] For excellent monographs on hypervalent iodine chemistry, see: a) A. Varvoglis, Hypervalent lodine in Organic Synthesis, Academic Press, London, 1997. b) Hypervalent lodine Chemistry: Modern Developments in Organic Synthesis (Ed.: T. Wirth), Topics in Current Chemistry, vol. 224, Springer, Berlin, 2003. c) V. V. Zhdankin, Hypervalent lodine Chemistry, John Wiley \& Sons, Chichester, 2014. d) b) Hypervalent lodine Chemistry (Ed.: T. Wirth), Topics in Current Chemistry, vol. 373, Springer, Berlin, 2016.

[3] a) M. Brown, U. Farid, T. Wirth, Synlett 2013, 24, 424; b) R. M. Romero, T. H. Wöste, K. Muniz, Chem. Asian J. 2014, 9, 972; c) M. Fujita, Tetrahedron Lett. 2017, 58, 4409.

[4] a) R. M. Moriarty, S. C. Gupta, H. Hu, D. R. Berenschot, K. B. White, J. Am. Chem. Soc. 1981, 103, 686; b) M. Ochiai, A. Nakanishi, T. Suefuji, Org. Lett. 2000, 2, 2923; c) K. M. McQuaid, T. R. R. Pettus, Synlett 2004, 2403; d) S. Lee, D. W. C. McMillan, Tetrahedron 2006, 62, 11413

[5] a) Y. N. Ito, T. Katsuki, "Oxidation of the $\mathrm{C}=\mathrm{C}$ bond" in Asymmetric Oxidation Reactions, (Ed.: T. Katsuki), Oxford University Press, 2001, ch. 2.1, pp. 19-37. b) T. Katsuki, Synlett 2003, 281

[6] For excellent overviews, see: a) M. P. Doyle, M. A. McKervey, T. Ye, Modern Catalytic Methods for Organic Synthesis with Diazo Compounds: From Cyclopropanes to Ylides, Wiley, New York, 1998; b) H. M. L. Davies, E. G. Antoulinakis, Org. React. 2001, 57, 1; c) M. P. Doyle, T. Ren, K. D. Karlin, Prog. Inorg. Chem. 2001, 49, 113; d) C. A. Merlic, A. L. Zechman, Synthesis 2003, 1137; e) H. M. L. Davies, R. E. J. Beckwith, Chem. Rev. 2003, 103, 2861; f) A. G. H. Wee, Curr. Org. Synth. 2006, 3, 499; g) H. M. L. Davies, J. R. Manning, Nature 2008, 451,417 ; h) M. P. Doyle, R. Duffy, M. Ratnikov, L. Zhou, Chem. Rev. 2010, 110, 704; i) A. Ford, H. Miel, A. Ring, C. N. Slattery, A. R. Maguire, M. A. McKervey, Chem. Rev. 2015, 115, 9981.

[7] S. P. Uemura, S. R. Patil, Chem. Lett. 1982, 1743.

[8] a) A. J. Catino, R. E. Forslund, M. P. Doyle, J. Am. Chem. Soc. 2004, 126, 13622; b) A. J. Catino, J. M. Nichols, H. Choi, S. Gottipamula, M. P. Doyle, Org. Lett. 2005, 7, 5167; c) E. C. McLaughlin, H. Choi, K. Wang, G. Chiou, M. P. Doyle, J. Org. Chem. 2009, 74, 730; d) M. O.
Ratnikov, M. P. Doyle, Mendeleev Comm. 2014, 24, 187; e) J. A. S. Coelho, A. F. Trindade, R. Wanke, B. G. M. Rocha, L. F. Veiros, P. M P. Gois, A. J. L. Pombeiro, C. A. M. Afonso, Eur. J. Org. Chem. 2013, 1471 ; f) Y. Wang, Y. Kuang, Y. Wang, Chem. Commun. 2015, 51, 5852; g) L. Zhao, Y. Wang, Z. Ma, Y. Wang, Inorg. Chem. 2017, 56, 8166; h) Y. Lin, L. Zhu, Y. Lan, Y. Rao, Chem. Eur. J. 2015, 21, 14937.

[9] D. Shabashov, M. P. Doyle, Tetrahedron 2013, 69, 10009.

[10] For reviews, see a) P. Müller, Acc. Chem. Res. 2004, 37, 243; b) M. S. Yusubov, A. Yoshimura, V. V. Zhdankin, Arkivoc 2016, i, 342. For some relevant examples, see: c) P. Müller, D. Fernandez, Helv. Chim. Acta 1995, 78, 947; d) R. P. Wurz, A. B. Charette, Org. Lett. 2003, 5, 2327; e) S. R. Goudreau, D. Marcoux, A. B. Charette, D. Hughes, Org. Synth. 2010, 87, 115; f) S. A. Wolckenhauer, A. S. Devlin, J. Du Bois, Org. Lett. 2007, 9, 4363; g) C. Zhu, A. Yoshimura, L. Ji, Y. Wei, V. N. Nemykin, V. V. Zhdankin, Org. Lett. 2012, 14, 3170.

[11] For reviews, see: a) P. Müller, C. Fruit, Chem. Rev. 2003, 103, 2905; b) P. Dauban, R. H. Dodd, Synlett 2003, 1571; c) J. W. W. Chang, T. M. U. Ton, P. W. H. Chan, Chem. Rec. 2011, 11, 331; d) J. Du Bois, Org. Process. Res. Dev. 2011, 15, 758; e) J. L. Roizen, M. E. Harvey, J. Du Bois, Acc. Chem. Res. 2012, 45, 911; f) D. Karila, R. H. Dodd, Curr. Org. Chem. 2011, 15, 1507; g) G. Dequirez, V. Pons, P. Dauban, Angew. Chem. 2012, 124, 7498; Angew. Chem. Int. Ed. 2012, 51, 7384; h) J. Buendia, G. Grelier, P. Dauban, Adv. Organomet. Chem. 2015, 64, 77.

[12] For relevant studies, see: a) R. Breslow, S. H. Gellman, J. Am. Chem. Soc. 1983, 105, 6728. b) P. Müller, C. Baud, Y. Jacquier, Tetrahedron 1996, 52, 1543; c) I. Nägeli, C. Baud, G. Bernardinelli, Y. Jacquier, M. Moran, P. Müller, Helv. Chim. Acta 1997, 80, 1087; d) C. G. Espino, J. Du Bois, Angew. Chem. 2001, 113, 618; Angew. Chem. Int. Ed. 2001, 40, 598; e) C. G. Espino, P. M. Wehn, J. Chow, J. Du Bois, J. Am. Chem. Soc. 2001, 123, 6935; f) K. Guthikonda, J. Du Bois, J. Am. Chem. Soc. 2002, 124, 13672; g) K. W. Fiori, J. Du Bois, J. Am. Chem. Soc. 2007, 129, 562; h) R. H. Perry, T. J. Cahill III, J. L. Roizen, J. Du Bois, R. N. Zare, Proc.Natl. Acad. Sci. USA 2012, 109, 18295; i) J. L. Roizen, D. N. Zalatan, J. Du Bois, Angew. Chem. 2013, 125, 11553; Angew. Chem. Int. Ed. 2013, 52, 11343; j) M. Anada, M. Tanaka, N. Shimada, H. Nambu, M. Yamawaki, S. Hashimoto, Tetrahedron 2009, 65, 3069; k) A. Nörder, S. A. Warren, E. Herdtweck, S. M. Huber, T. Bach, J. Am. Chem. Soc. 2012, 134, 13524; I) C. Liang, F. Collet, F. Robert-Peillard, P. Müller, R. H. Dodd, P. Dauban, J. Am. Chem. Soc. 2008, 130, 343; m) J. Ciesielski, G. Dequirez, P. Retailleau, V. Gandon, P. Dauban, Chem. Eur. J. 2016, 22, 9338 ; n) J. Buendia, B. Darses, P. Dauban, Angew. Chem. 2015, 127, 5789; Angew. Chem. Int. Ed. 2015, 54, 5697; o) J. Buendia, G. Grelier, B. Darses, A. G. Jarvis, F. Taran, P. Dauban, Angew. Chem. 2016, 128, 7656; Angew. Chem. Int. Ed. 2016, 55,7530 .

[13] a) B. Darses, R. Rodrigues, L. Neuville, M. Mazurais, P. Dauban, Chem Commun. 2017, 53, 493; b) D. Hazelard, P.-A. Nocquet, P. Compain, Org. Chem. Front. 2017, 4, 2500.

[14] C. G. Espino, K. W. Fiori, M. Kim, J. Du Bois, J. Am. Chem. Soc. 2004 126, 15378

[15] D. Clemente-Tejeda, A. Lopez-Moreno, F. A. Bernejo, Tetrahedron 2013, 69, 2977.

[16] Though the difference in yields between the entries 12 and 13 is not significant, the choice of Phl(OPiv) $)_{2}$ as the oxidant to study the scope of the reaction was motivated by the reaction of alkene $1 \mathrm{i}$ with $\mathrm{Phl}(\mathrm{OAc})_{2}$ that leads to the expected epoxide $2 \mathbf{i}$ in only $40 \%$ yield $(70 \%$ with $\mathrm{Phl}(\mathrm{OPiv})_{2}$; see table 2)

[17] The reaction with a tetrasubstituted alkene only leads to the recovery of the starting material.

[18] An allylic alcohol such as geraniol does not afford the corresponding epoxide under the reaction conditions. A complex mixture of products, instead, is obtained as indicated by the ${ }^{1} \mathrm{H}$ NMR of the crude.

[19] In order to circumvent the lack of reactivity of $\alpha, \beta$-unsaturated ketones, these were converted to cyclic ketals. However, application of the 
reaction conditions to the latter only leads to the starting ketone following cleavage of the ketal.

[20] It is worth mentioning that the reaction of $m$-CPBA with the ortho-cyano styrene only leads to the corresponding epoxide $2 \mathrm{~s}$ in $13 \%$ yield. See: "ACC inhibitors and uses thereof", PCT/ WO 2013071169A1, May 16, 2013.

[21] K. Miyamoto, N. Tada, M. Ochiai, J. Am. Chem. Soc. 2007, 129, 2772.

[22] Use of other Lewis acids such as $\mathrm{Cu}(\mathrm{OTf})_{2}, \mathrm{Pd}(\mathrm{OAc})_{2}, \mathrm{BF}_{3} . \mathrm{OEt}_{2}$, $\mathrm{Sc}(\mathrm{OTf})_{3}, \mathrm{CeCl}_{3}, \mathrm{LiCl}$, or TMSOTf, in the epoxidation of $1 \mathrm{i}$ leads to either its decomposition or the formation of the expected product $\mathbf{2} \mathbf{i}$ in very low yield.

[23] For a previous Lewis acid-catalyzed olefin epoxidation with an iodine(III) oxidant, see: Y. Yang, F. Diederich, J. S. Valentine, J. Am. Chem. Soc. 1991, 113, 7195.

[24] The electron-withdrawing property of the ligand on the dirhodium complex would allow for tuning its Lewis acidity. The latter should be Lewis acidic enough for the activation of the hypervalent iodine reagent, however, a too strong Lewis acid is likely to increase its oxidizing character thereby inducing the decomposition of the resulting epoxide, as demonstrated by the study of Ochiai (see ref. 21).

[25] It should be mentioned that a recent theoretical study supports a metathesis mechanism for the functionalization of alkenes using a hypervalent fluoroiodine reagent. J. Zhang, K. J. Szabo, F. Himo, ACS Catal. 2017, 7, 1093
[26] P. Šiška, D. Danková, C. Nitrayová, P. Fodran, I.Špánik, P.Szolcsányi, Synth. Commun. 2017, 47, 1582

[27] A. Méou, M. A. Garcia, P. Brun, J. Mol. Catal. A Chem. 1999, 138, 221.

[28] O. P. Vig, I. R. Trehan, G. L. Kad, J. Ghose Indian J. Chem. 1983, 22B, 515.

[29] H. Steinmetz, J. Li, C. Fu, N. Zaburannyi, B. Kunze, K. Harmrolfs, V. Schmitt, J. Herrmann, H. Reichenbach, G. Höfle, M. Kalesse, R. Müller Angew. Chem. Int. Ed. 2016, 55, 10113.

[30] Y. H. Kim, B. C. Chung, J. Org. Chem. 1983, 48, 1562.

[31] A. Mordini, D. Peruzzi, F. Russo, M. Valacchi, G. Reginato, A. Brandi, Tetrahedron 2005, 61, 3349.

[32] T. J. Harrison, P. M. A. Rabbat, J. L. Leighton, Org. Lett. 2012, 14, 4890.

[33] J. Tsuji, H. Kataoka, Y. Kobayashi, Tetrahedron Lett. 1981, 22, 2575.

[34] Z.-X. Wang, Y. Tu, M. Frohn, J.-R. Zhang, Y. Shi, J . Am. Chem. Soc. 1997, 119, 11224.

[35] L. A. Flippin, P. A. Brown, K. Jalali-Araghi, J. Org. Chem. 1989, 54, 3588.

[36] T. Mukaiyama, K. Imagawa, T. Yamada, T. Takai, Chem. Lett. 1992, 21, 231.

[37] S. Pedragosa-Moreau, C. Morisseau, J. Zylber, A. Archelas, J. Baratti, R. Furstoss, J. Org. Chem. 1996, 61, 7402.

[38] S. Qian, T. He, W. Wang, Y. He, M. Zhang, L. Yang, G. Li, Z. Wang, Bioorg. Med. Chem. 2016, 24, 6194. 
Entry for the Table of Contents (Please choose one layout)

\section{FULL PAPER}

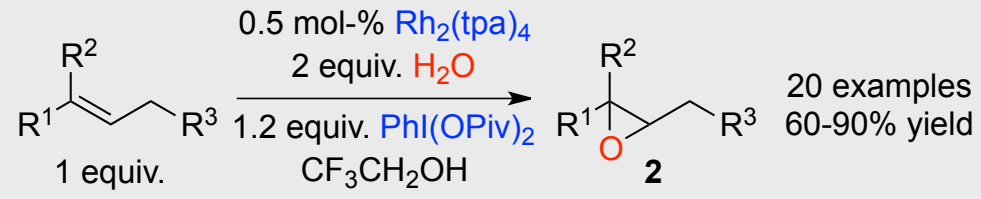

Switch O-N. The combination of rhodium(II) catalysis and iodine(III) oxidant, which is well acknowledged for inducing nitrogen atom transfer, is shown to promote an unusual alkene epoxidation in the presence of water. The reaction would involve a Lewis acidic dirhodium(II) complex bound to an iodonium species that would undergo nucleophilic displacement with water.

\section{Alkene epoxidation*}

Ali Nasrallah, Gwendal Grelier, Maria Ivana Lapuh, Fernando J. Duran, Benjamin Darses, Philippe Dauban*

Page No. - Page No.

Dirhodium(II)-mediated alkene epoxidation with iodine(III) oxidants 